\title{
6 spørgsmål om klima - og 36 spcendende svar
}

\section{Af Ulla V. Hjuler, GeologiskNyt}

"Den danske regering har som overordnet mål, at COP15-konferencen i København skal resultere i en ambitiøs global aftale, der omfatter alle Verdens lande og som sætter ambitiøse mål for reduktion af de globale drivhusgasudledninger”, kan man læse på Klima- og Energiministeriets hjemmeside.

Klimadebatten fylder efterhånden meget i nyhedsmedierne - både "lokalt" inden for landets grænser og på verdensplan. Mange ser med forventning frem til COP15, den
15. konference for underskriverne af FN's klimakonvention (UNFCCC), et møde der finder sted i år fra d. 7.-18. december i København. På hjemmesiden for Klimakonferencen (http://da.cop15.dk) kan man bl.a. læse, at "mødet er et af de vigtigste nogensinde”, og at det "vil have en langt større rækkevidde og mulig indvirkning på Verden end for eksempel Wienerkongressen i 181415”. Der er delte meninger om udfaldet af konferencen i København - nogle er yderst optimistiske og forventer, at der kommer klare aftaler i stand om bl.a. reduktion af udledning af drivhusgasser - andre er mere skeptiske og tror ikke på, at mødet fører til konkrete handlingsplaner.

GeologiskNyt har stillet en række personer, der beskæftiger sig med klima, de føl- gende 6 spørgsmål, der bl.a. drejer sig om global opvarmning og deres forventninger til klimakonferencen i år.

1) Hvad mener du, er den primære årsag til global opvarmning?

2) Er der nogle myter om global opvarmning, som, du mener, kan være misvisende i debatten?

3) Inden for hvilket forskningsområde synes du, at der bør afsættes (flere) penge - og hvad skal de bruges til?

4) Kan vi gøre noget selv for at mindske den globale opvarmning?

5) Hvad forventer du, at der kommer ud af klimakonferencen i København senere i år? 6) Hvordan tror du, at den "globale" temperatur ser ud om 100 år?
1) Hvad mener du, er den primære årsag til global opvarmning?

En liste over vigtige årsager til den globale opvarmning, vi netto har oplevet i det 20. Århundrede, vil se således ud: Oceanografiske variationer, skydækkevariationer, ændringer i atmosfærisk vanddamp, $\mathrm{CO}_{2}$ og støv, ændret arealudnyttelse samt forskellige ekstraterristiske fænomener, bl.a. variationer i solaktivitet.

\section{2)Er der nogle myter om global opvarmning, som, du mener, kan være misvisende i debatten?}

En liste over ofte fremførte, men misvisende, udsagn ser således ud:
- $\mathrm{CO}_{2}$ har dominerende effekt på den globale temperatur.

- Sol og andre ekstraterrestriske fænomener har kun ubetydelig effekt på klimaet.

- Den globale temperatur stiger fortsat og kraftigere end forudsagt (se figur).

- Klimamodeller er troværdige og kan benyttes til politiske beslutninger.

- Levevilkår bliver generelt dårligere, når den globale temperatur stiger.

3) Inden for hvilket forskningsområde synes du, at der bør afsættes (flere) penge - og hvad skal de bruges til?

Afsæt væsentligt flere midler til grundforskning, er det generelle svar. Fri grund- forskning ved universiteter har gennem århundreder været den kulturelle løftestang for alle udviklede lande. Sandsynligvis vil det også være sådan i fremtiden. Den øjeblikkelige politiske manglende forståelse for den fri grundforsknings betydning er meget bekymrende.

Et klimaspecifikt svar vil være en anbefaling af mere vægt på grundforskning knyttet til oceanografi, skydække, sol og andre ekstraterrestriske klimafænomener. Desuden bør grundforskning om fortidens klimaændringer og deres effekter på landskaber og levevilkår vægtlægges i stort omfang. Et forbedret kendskab til fortidens klimavariationer er naturligvis helt afgørende for sikker identifikation af mulige menneskabte klimaeffekter i nutidens klima. 


\section{4) Kan vi gøre noget selv for at mindske den globale opvarmning?}

Vi påvirker det regionale klima ved ændret arealudnyttelse. Generelt vil jeg dog ikke tilråde forsøg på aktivt at gribe ind i en kompleks og endnu kun ufuldstændigt kendt problemstilling. Der er også en stor mulighed for, at naturlige klimaændringer over de næste 100 år løser problemet, i det omfang man overhovedet står over for et reelt problem. Se nedenfor.

\section{5) Hvad forventer du, at der kom- mer ud af klimakonferencen i}

\section{København senere i år?}

Det vil sandsynligvis være uhyre vanskeligt at komme frem til en aftale, der er konkret, bindende og faktisk resulterer i de ønskede reduktioner i mængden af $\mathrm{CO}_{2}$ produceret ved forbrug af fossile brændstoffer.

Hvis en post-Kyoto aftale skal anses som meningsfuld af tilhængerne af $\mathrm{CO}_{2}$-hypotesen, vil det kræve, at både Kina og Indien er med fuldt og helt i aftalen. Kina og Indien har imidlertid gjort det klart, at de kun medvirker, hvis Vesten betaler prisen derfor. Et alvorligt problem er naturligvis, at de vestlige lande allerede i øjeblikket har store vanskeligheder ved at opfylde den eksisterende Kyoto-aftale. Et problem i en helt anden størrelsesorden vil imidlertid opstå, hvis de også skal financiere en post-Kyoto aftale ikke kun for sig selv, men også for en lang række udviklingslande. At dette tidsmæssigt sammenfalder med en alvorlig international finanskrise gør en konkret og bindende aftale i København lidet sandsynlig. Vælgerne vil ikke betale prisen herfor, og da slet ikke, når en berettiget tvivl om $\mathrm{CO}_{2}$-hypotesen samtidig breder sig.

Det er tænkeligt, at nogle af $\mathrm{CO}_{2}$-hypotesens mest ivrige tilhængere aktivt vil arbejde for et sammenbrud i København, da de ikke vil anse det opnåelige som tilstrækkeligt. Andre tilhængere af $\mathrm{CO}_{2}$-hypotesen vil derimod anse en fiasko som en alvorlig afbrydelse af det politiske momentum, der i øjeblikket er bygget op omkring $\mathrm{CO}_{2}$-hypotesen. For dem understreges alvoren ved et sammenbrud af det forhold, at den globale temperatur siden årtusindskiftet ikke længere stiger, men til og med nu viser en svagt faldende tendens. Dette gør i manges øjne nu $\mathrm{CO}_{2}$-hypotesen utroværdig. En fiasko i København vil dermed bringe hele det politiske momentum knyttet til $\mathrm{CO}_{2}$-hypotesen i fare.

Et muligt hændelsesforløb i København kan skitseres således: At undlade at tage konkrete beslutninger vil ikke være en realistisk politisk mulighed. Den mulighed blev opbrugt på Bali-mødet i 2007 og kan ikke gentages.

Opnår man ikke enighed om en bindende $\mathrm{CO}_{2}$-aftale i København, vil der derfor

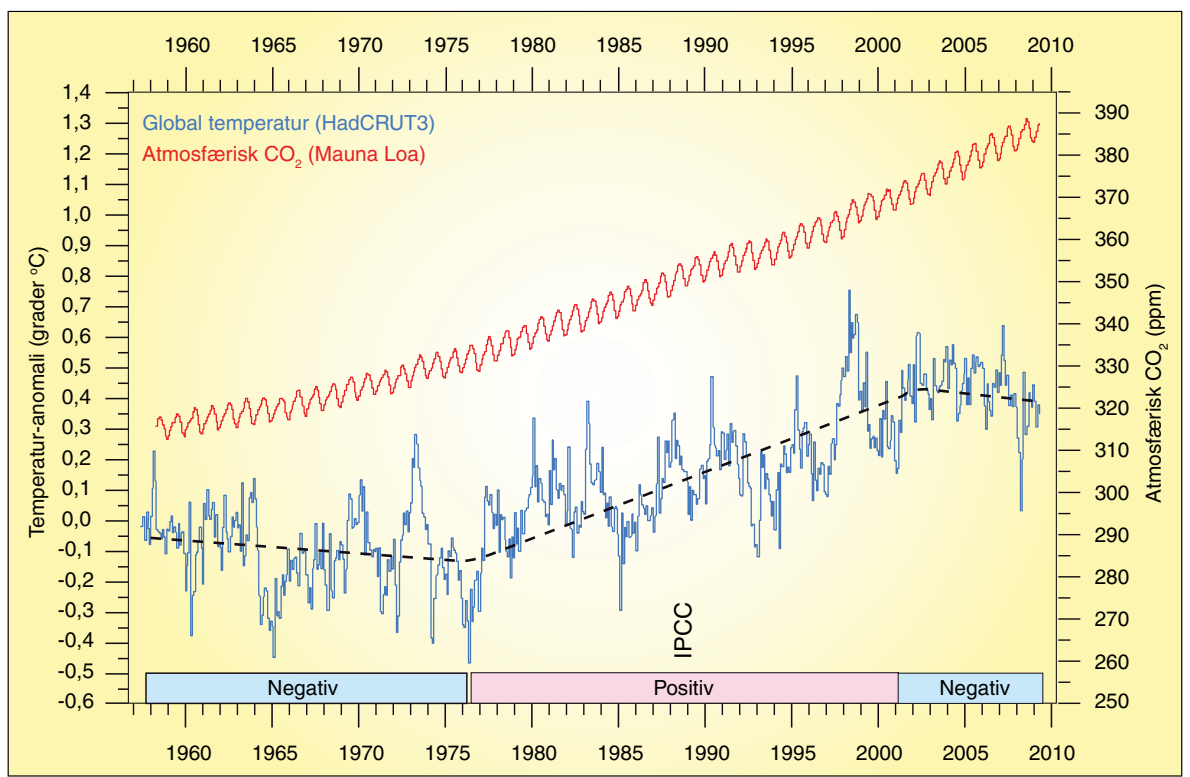

Mcengden af atmosfcerisk $\mathrm{CO}_{2}$ og global månedstemperatur siden 1958. Temperaturerne er vist i forhold til reference(normal)perioden 1961-1990. CO -målingerne påbegyndtes i 1958, hvorfor dette er valgt som starttidspunkt i diagrammet. Figuren er opdateret til og med februar 2009. Boksene angiver relationen mellem $\mathrm{CO}_{2}$ og temperatur. IPCC angiver oprettelsen af FN's klimapanel. (Grafik: UVH modificeret efter forfatterens forlceg)

kun være en mulighed tilbage for politikerne til at redde ansigt: I det øjeblik forhandlingerne måtte blive vanskelige, vil presset hurtig bygges op i forhold til de nationer, der er mest tilbageholdende med at indgå en aftale. Før eller siden vil en eller flere af disse nationer da påpege, at klimaforskningen faktisk ikke er så entydig endda. Allerede nu tales der i politisk sammenhæng ikke længere om "Global Warming”, men derimod ofte om "Climate Change". Tænk blot på selve overskriften til Københavnkonferencen: "Scientific Congress about Climate Change". Ikke et ord om "Global Warming”. Også præsident Obama har for nylig benyttet udtrykket "listening to what scientists have to say".

Straks en eller flere af de politiske ledere åbent indrømmer, at der faktisk er stor tvivl om den fremtidige klimaudvikling, vil en syndflod af tilsvarende udsagn udløses. Dernæst vil man rask se dagens klimabekymringer forsvinde hos politikere, hvorefter de frit kan fokusere på de reelle problemer, som der er rigeligt af.

Connie Hedegaard står bestemt over for en både vanskelig og interessant udfordning.

\section{Hvordan tror du, at den "globale" temperatur ser ud om 100 år?}

Det er der ingen der ved, da det afhænger af forhold, der hører fremtiden til. Men med kendskab til fortidens klimavariationer vil jeg ikke anse det som usandsynligt, at vi i løbet af de næste 100 år oplever et par perioder med både temperaturfald og temperaturstigning. Jeg vil derfor ikke være overrasket, hvis den globale temperatur om 100 år ender inden for et interval fra -0,7 til $+0,7$ grader i forhold til den nuværende temperatur. Jeg vil derimod anse det som lidet sandsynligt, at IPCC's forudsigelse om 2-6 graders global temperaturstigning bliver en realitet. For da slet ikke at tale om de 6 graders temperaturstigning inden 2050, der for nylig oplystes til deltagerne på World Economic Forum som del af deres beslutningsgrundlag.

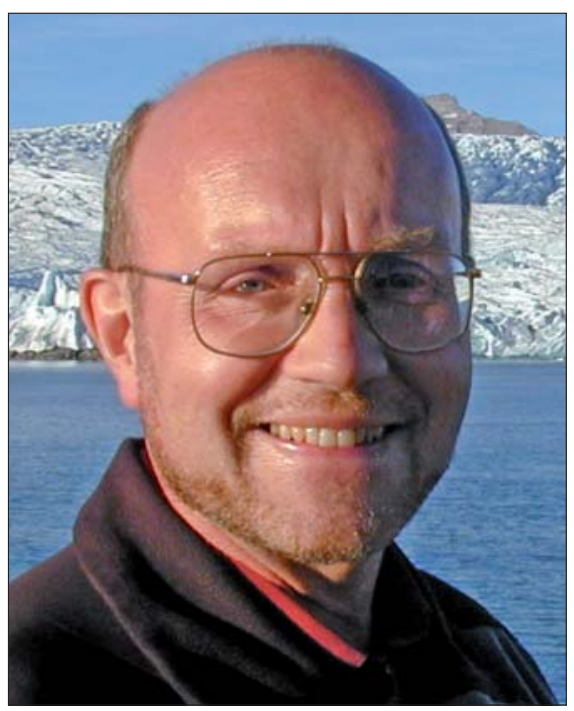

Ole Humlum (f. 1949) er professor i fysisk geografi ved Oslo Universitet. 


\section{Eigil Kaas}

1) Hvad mener du, er den primære årsag til global opvarmning?

Den tiltagende opvarmning af planeten kan kun skyldes en ubalance mellem den energi, planeten pt. modtager og det, den afgiver til verdensrummet. Der kan være såkaldt interne naturlige variationer i denne energi (på grund af variationer oceaniske og atmosfæriske cirkulationsmønstre som fx El Niño), men disse kan tildels afdækkes ved grundige målinger af systemet. Der kan også være forcerede påvirkninger fra vulkaner, sol-aktivitet og menneskeskabte aktiviteter. Betydningen af vulkansk aktivitet kan estimeres vha. satellitdata, og når man går længere tilbage vha. samtidige iskernedata fra Antarktis og Grønland. Variationer i solaktivitet (og dermed også fx variationer i kosmisk stråling) kan estimeres ud fra en række forskellige målinger.

Resultatet af alt dette er med dagen bedste viden: Der forekommer interne variationer i klimasystemet, som giver visse op- og nedture i den energi, planeten modtager og afgiver. Når det gælder den generelle udvikling over de seneste 50 år, er det uomtvisteligt, at tiltagende atmosfærisk indhold af drivhusgasser - især $\mathrm{CO}_{2}$ - isoleret set har medført en markant ubalance i energiforholdene. Disse er i nogen grad blevet modvirket af menneskeskabte udslip af små partikler - såkaldte aerosoler.

Solaktiviteten har igennem de seneste ca. 50 år været stort set uforandret (bortset fra de almindelige 11-års cykler). Lige nu er solaktiviteten ret lav og har givet et lille afkølende bidrag de allerseneste år. Vulkansk påvirkning har været domineret af udbruddet fra Pinatubu i 1991 og umiddelbart derefter. Alt ialt har $\mathrm{CO}_{2}$ og andre drivhusgasser bidraget med en del over 100 \% til opvarmningen de seneste 30-40 år. At det bliver over $100 \%$, skyldes de nævnte afkølende effekter.

\section{2) Er der nogle myter om global opvarmning, som, du mener, kan være misvisende i debatten?}

Eksempler på myter (der altså er forkerte):

a) Stigende $\mathrm{CO}_{2}$ i atmosfæren skyldes ikke menneskelig aktivitet.

b) Temperaturen i troposfæren inkl. den tropiske troposfære er ikke stigende.

c) Solaktivitet har bidraget til de seneste 30 40 års globale opvarmning.

d) Vanddamp kan være andet end en feedback.

e) De allerseneste års temperaturfald i forhold til 1998 kan tages til indtægt for, at $\mathrm{CO}_{2}$ ikke har nogen stor opvarmende effekt.

\section{3) Inden for hvilket forskningsom-} råde synes du, at der bør afsættes (flere) penge - og hvad skal de bruges til?

Der bør afsættes midler til at forstå klimasystemet endnu bedre, fordi der er en lille mulighed for, at klimaændringerne som følge af menneskeskabt aktivitet kan blive endnu større end hidtil beregnet eller alternativt lidt mindre. Der skal også afsættes midler til energibesvarelser samt forskning i nye energiteknologier og integrerede energisystemanalyser.

\section{4) Kan vi gøre noget selv for at mindske den globale opvarmning?}

Ja, en masse. Men det batter først rigtig, når politikerne for alvor tager lederskab og bruger både "pisk og gulerod" samt foretager de korrekte samfundsinvesteringer. Vi undgår ikke at spare på energien, men hvis vi er smarte, behøver det ikke gøre så ondt (med mindre man fx er meget glad for at køre $130 \mathrm{~km} / \mathrm{t}$ på motorvej i stedet for fx 90 eller 100). Der kræves altså en del beslutninger, der går i modsat retning af det umiddelbart populistiske. Det vil under alle omstændigheder - klimaændringer eller ej - være en god ide at spare på energien.

\section{5) Hvad forventer du, at der kom- mer ud af klimakonferencen i Kø- benhavn senere $\mathrm{i}$ år?}

Jeg håber på en masse, men er desværre bange for, at klimaændringer reelt ikke står tilstrækkeligt højt på dagsordenen hos mange politikere.

6) Hvordan tror du, at den "globale” temperatur ser ud om 100 år?

Jeg er ikke særligt religiøs, så det vil jeg lade alverdens kirker komme med et bud på. Beregninger over klimaændringer ligger på omkring 3 graders stigning globalt set, i forhold til anno 2000, men med betydelig usikkerhed.

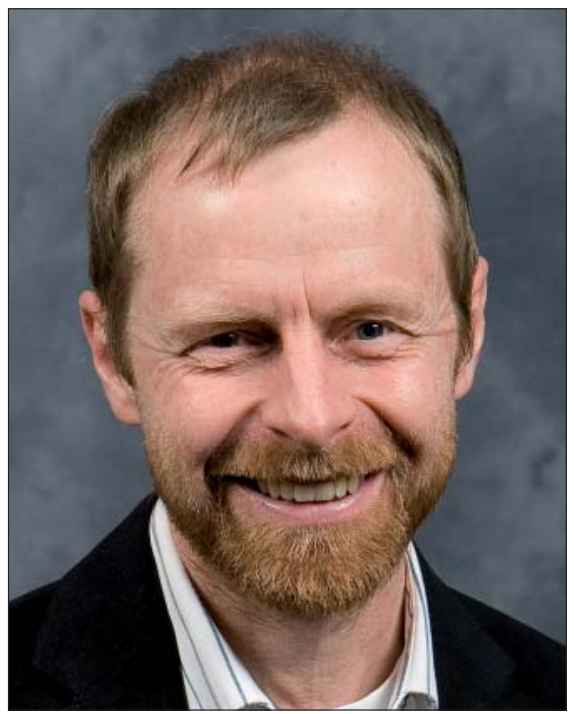

Eigil Kaas (f. 1958) er professor i meteorologi på Niels Bohr Institutet i København. 


\section{Connie Hedegaard}

1) Hvad mener du, er den primære årsag til global opvarmning?

Der er ingen tvivl i mit sind om, at den opvarmning, vi har set de seneste 50 år, først og fremmest skyldes de enorme mængder af drivhusgasser, vi har lukket ud i atmosfæren. I denne sag støtter jeg mig primært til de grundige udredningsrapporter fra FN's Klimapanel. I den seneste rapport fra 2007 har en bred skare af verdens bedste klimaforskere vurderet, at tegnene på global opvarmning er uomtvistelige. Der findes en række indikatorer, som viser, at klimaet forandrer sig hastigt i disse år, og jeg er overbevist, når forskerne siger, at denne udvikling med 90 procent sikkerhed skyldes effekten fra de menneskeligt udledte drivhusgasser.

I sidste ende er det et valg, hver eneste af os må tage: Vil vi ignorere advarslerne og håbe, at det nok går - eller vil vi følge rådene fra FN’s klimapanel. Råd, der siger: I må handle og jo længere, I tøver, des værre og dyrere bliver det.

\section{2) Er der nogle myter om global opvarmning, som, du mener, kan være misvisende i debatten?}

Det har været fremme i pressen, at den globale opvarmning skulle være stoppet, fordi 2008 globalt set var det koldeste år siden 1998. Rekordåret 1998 var det hidtil varmeste, og 2008 var det 10 . varmeste år, siden globale målinger startede i 1850. Det er ikke det samme som, at den globale opvarmning er stoppet. I samme måleserie ligger de 10 varmeste år målt således fra 1997 og frem. Vi vil se varme og kolde år også i fremtiden. Det er i mine øjne useriøst at slå dette udslag af ganske naturlige temperatursvingninger op, som det er sket i visse medier.

\section{3) Inden for hvilket forskningsom- råde synes du, at der bør afsættes (flere) penge - og hvad skal de bru- ges til?}

Vi er nødt til at forbedre vores viden om fremtidens regionale klimaforandringer. Dels for at få bedre styr på, hvad det vil koste ikke at gøre noget ved årsagerne til disse forandringer, dels for at vi bedre kan tilpasse os fremtidens klima. Fordi det går så stærkt i disse år, er vi også nødt til at blive bedre til at overvåge klimaforandringerne meget tættere, end vi har gjort hidtil. Det er afgørende for vores tilpasningsevne, at vi har de bedste modeller og den nyeste viden om klimaet i fremtiden på såvel kort som langt sigt. Her er det blandt andet vigtigt at forske i klimatilpasning, og hvilke forholdsregler vi kan træffe på forhånd. Samtidig er også arktisk forskning en vigtig måde at få viden om vores klode på. Men samtidig er vi også nødt til at få opfundet de teknologiske løsninger, der skal til.

Regeringen har blandt andet derfor valgt at styrke energiteknologiområdet betragteligt i disse år, og i 2010 vil der være 1 mia. kr. til rådighed. Jeg ved, at der er potentiale til at udnytte alle disse midler fornuftigt, og det er min ambition, at vi kan opretholde et højt ambitionsniveau på dette område i mange år frem til glæde for klimaet og dansk erhvervsliv.

\section{4) Kan vi gøre noget selv for at mindske den globale opvarmning?}

Ja, det kan vi bestemt. Store dele af regeringens politik er netop møntet på, at borgerne skal tage klimadagsordenen til sig. Her taler jeg blandt andet om regeringens nye trafikinvesteringsplan, der giver 2 ud af 3 kroner til offentlig transport, de høje afregningspriser til vedvarende energi, som blev vedtaget i det brede energiforlig fra sidste år, satsning på energieffektivisering i både staten, kommunerne og ude hos borgerne, der med regeringens nye pulje til renovering, selv kan skrue ned for deres energiforbrug. Det er vigtigt med såvel strukturelle tilpasninger af vores energisystemer som omstilling til nye vedvarende energikilder.

For den enkelte borger handler det primært om energieffektivisering og omhu med ressourcerne, hver gang vi tager en beslutning. Med kampagnen 1 Ton Mindre kan den enkelte borger selv se, hvor der kan spares på både energiforbruget - og regningen.

5) Hvad forventer du, at der kommer ud af klimakonferencen i København senere $i$ år?
Danmark arbejder for at få en ambitiøs global aftale, der binder alle lande sammen omkring et fælles mål om at bekæmpe klimaforandringerne. Det handler både om, at vi i de rige lande så hurtigt som muligt får nedsat udledningerne af drivhusgasser, men vi skal samtidig sikre U-landene mulighed for fortsat udvikling og tilpasning til fremtidens klima under anvendelse af den bedst mulige teknologi.

\section{6) Hvordan tror du, at den "globa- le” temperatur ser ud om 100 år?}

Forhåbentlig kan vi med en bindende aftale i København i december se frem til et klima, hvor vi mindsker effekten af menneskeligt udledte drivhusgasser, som påvirker den globale middeltemperatur. Vi skal have vendt udviklingen og arbejde for at begrænse stigningen i den globale middeltemperatur, i forhold til den præ-industrielle temperaturudvikling, til de 2 grader, som vi i EU - blandt andet på baggrund af IPCC's vurderinger - anbefaler som det langsigtede mål.

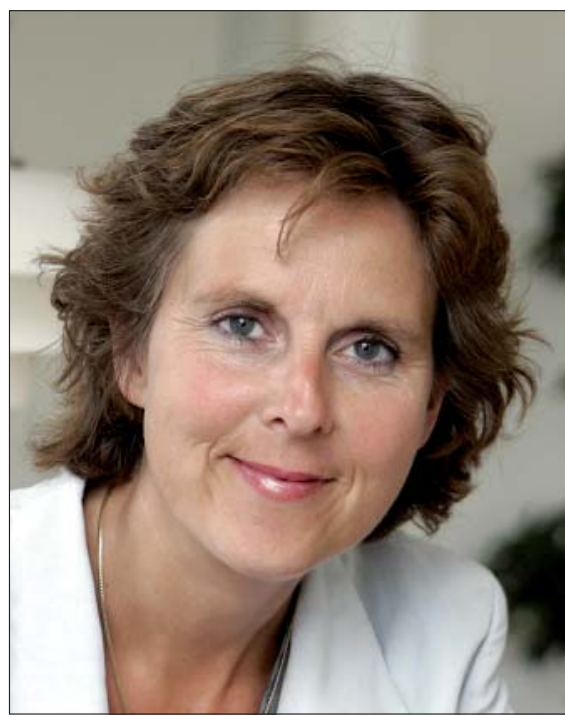

Connie Hedegaard (f. 1960) er Klima- og Energiminister 


\section{Bjarne Andresen}

\section{1) Hvad mener du, er den primære årsag til global opvarmning?}

Nu er der videnskabeligt set ikke noget, der korrekt kan gå under betegnelsen "global opvarmning”. Men hvis der med spørgsmålet menes den primære årsag til ændringer af det globale klima, er der overhovedet ingen tvivl om, at den primære drivende kraft er naturen selv. Det kan være ustabiliteter i Jordens mange flow-systemer, ændringer i solens udstråling, baneændringer inden for Mælkevejen, udviklingen af organismerne på Jorden, herunder mennesket, og mange andre muligheder. Vi ved endnu for lidt til med nogen sikkerhed at kunne tilskrive alle disse faktorer kvantitative betydninger. Forsøger nogen alligevel, er det i vid udstrækning gætværk eller ønsketænkning.

Klimaet har til alle tider undergået forandringer, til tider endda meget store forandringer, så det et helt naturligt, at der også i dag sker ændringer. Det ville være unaturligt, hvis der ikke skete ændringer.

\section{2) Er der nogle myter om global opvarmning, som, du mener, kan være misvisende i debatten?}

Skråsikre udtalelser, som ikke er fast forankret i basale fysiske principper. Alt for ofte ses velmenende personer, som emotionelt har fundet deres svar, opstille deres modeller og antagelser således, at netop dette svar "uomgængeligt” fremkommer. Der er en hårfin balance mellem idealisme og demagogi.

Videnskaben er ikke hjulpet af pågående politikere og interesseorganisationer med deres til tider ret unuancerede PR-apparater. Når der går politik, prestige og store penge i et emne, lider sandheden og de videnskabelige nuancer. Hvor megen ærlig videnskab kommer der egentlig ud af den store klimakonference i København til efteråret og Københavns Universitets stort opreklamerede klimamøde her i marts?

Der er et par helt fundamentale fakta omkring begrebet klima, som mange, ikke mindst sort-hvidtseende journalister og politikere, bør holde sig for øje:

Klima er en gennemsnitlig opførsel af det daglige vejr. Vejret ændrer sig meget fra time til time, fra dag til dag, fra år til år. Netop på grund af disse store variationer må gennemsnit tages over ganske lange perioder for overhovedet at have mening. Det er inkonsistent at udtale sig om, at klimaet har ændret sig i det sidste par år. Lad mig i den forbindelse minde om, at den udråbte kraftige opvarmning i 80'erne og 90'erne tilsyneladende er fladet ud i dette århundrede, og at alle talte om en overhængende istid i 70erne. Alle disse udtalelser er utroværdige, fordi tidshorisonten er alt for kort.

Klimaet er under stadig, naturlig, forandring. Vi har haft istider og varme mellemistider. Temperaturændringer var (i hvert fald medvirkende) årsag til nordboernes uddøen på Grønland og svenskernes invasion af Danmark over isen. Store meteornedslag har fra tid til anden været årsag til store temperaturfald og mange arters udslettelse. Den største klimakatastrofe af alle må vist være den fotosyntese, som tidligt i Jordens udvikling ændrede atmosfæren fra at være reducerende til at blive oxiderende. Jordens organismer har altid måttet indrette sig og har taget forandringerne som udfordringer, der faktisk har drevet udviklingen, fx opblomstringen af pattedyrene efter dinosaurernes uddøen.

\section{3) Inden for hvilket forskningsom- råde synes du, at der bør afsættes (flere) penge - og hvad skal de bru- ges til?}

Det har altid været en af menneskets største drivkræfter at forsøge at forstå naturen og ikke mindst forudsige fremtiden. I denne søgen indgår geovidenskab, astronomi, fysik, kemi og en lang række andre naturvidenskabelige discipliner. De er alle nødvendige og har alle brug for flere forskningsmidler til fri ubunden forskning. Jeg ønsker derfor ikke at fremhæve et område på bekostning af andre.

Det problem, som dybest set ligger bagved den store politiske og populistiske bevågenhed omkring klimaforandringer, er ikke, om klimaet bestemte steder nu bliver lidt varmere, koldere, vådere eller tørrere, men om mennesker kommer op at slås på grund af ændrede livsmuligheder. Skulle jeg derfor endelig forslå et område, hvor der specifikt er brug for øget indsats, er det konfliktforskning.

\section{4) Kan vi gøre noget selv for at}

mindske den globale opvarmning?

Kun marginalt. Mennesket har, hvad enten vi kan lide det eller ej, kun en lille rolle i naturens store spil.

5) Hvad forventer du, at der kommer ud af klimakonferencen i København senere $\mathrm{i}$ år?

Megen politisk og journalistisk ståhej samt en stribe meget dyre hovsa-løsninger, hvis effekt er tvivlsom og uden solidt videnskabeligt fundament.

\section{6) Hvordan tror du, at den "globa- le” temperatur ser ud om 100 år?}

Det er meget sigende, at der spørges om "tror", for ingen kan med sikkerhed sige noget konkret om Jordens tilstand om 100 år. Der er et stort mål af subjektivitet i enhver forudsigelse.

$\mathrm{Nu}$ findes der jo ikke nogen "global temperatur”, men hvis spørgsmålet egentlig drejer sig om Jordens klima om 100 år, så vil der givet være områder, der er blevet varmere, nogle der er blevet koldere, nogle der er blevet tørrere, og nogle der har fået mere regn. Jorden vil, som altid, have ændret sig, og det må mennesker bare leve med og indrette sig efter.

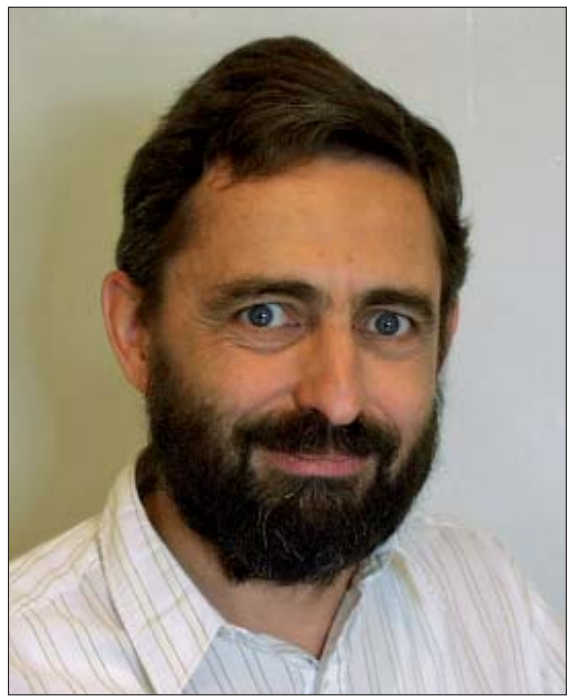

Bjarne Andresen (f. 1949) er lektor, dr. scient. i fysik på Niels Bohr Institutet i København. 


\section{Jesper Theilgaard}

\section{1) Hvad mener du, er den primære årsag til global opvarmning?}

Set i lyset af den udvikling, der har været af atmosfærens indhold af drivhusgasser siden 1850'erne, hvor mennesket begyndte at afbrænde fossile brændsler i større mængder, så er der for mig ingen tvivl om, at den forstærkede drivhuseffekt er den primære årsag til, at temperaturen kloden over stiger.

Allerede i 1896 beskrev Svante Arrenius, at afbrændingen af fossile brændsler vil kunne ændre klimaet. Eftertiden har vist, at han havde ret.

\section{2) Er der nogle myter om global opvarmning, som, du mener, kan være misvisende i debatten?}

Klimadebatten er fyldt med myter, hvoraf kan nævnes:

- jo mere $\mathrm{CO}_{2}$ i atmosfæren jo bedre, for så gror planterne bedre og hurtigere. (Muligvis gror planterne bedre, men konsekvenserne af den øgede mængde $\mathrm{CO}_{2}$ er langt værre end det beskedne positive bidrag fra vækstforøgelsen)

- mennesket er så lille i sammenligning med "Moder Natur", at vi slet ikke er i stand til at påvirke hende. (Nej, det er tydeligt, at indholdet af drivhusgasserne er steget betydeligt på grund af menneskets afbrænding a fossile brændsler)

- Værdien af tilbagestrålingen fra den forøgede drivhuseffekt er langt mindre end Solens variation. (Nej, det forholder sig omvendt - tilbagestrålingen er forøget med 3 - $4 \mathrm{~W} / \mathrm{m}^{2}$, men solvariationen er under 1 $\mathrm{W} / \mathrm{m}^{2}$ ved jordoverfladen)

- Havet er i stand til at optage mere $\mathrm{CO}_{2}$, end mennesket udleder. (Nej, jo varmere vandet er, jo mindre kan det optage. Samtidig stiger forsuringen af havet til stor skade for alt levende deri)

- Det er for dyrt at reducere udledningen af drivhusgasserne. (Det er ikke bevist, og muligheden for en grøn industriel revolution er til stede, så den samlede investering mindskes)

\section{3) Inden for hvilket forskningsom-} råde synes du, at der bør afsættes

\section{(flere) penge - og hvad skal de bru- ges til?}

De teknologiske forskningsområder skal styrkes med det primære formål at videreudvikle de vedvarende energikilder. Men det skal ske på en sådan måde, at hele den nationale og for så vidt globale energiudveksling vil være i stand til at aftage de nye energikilder. Det indebærer for eksempel, at når der produceres for meget energi, skal den kunne opmagasineres og anvendes, når produktionen falder. Problemet er velkendt i.forbindelse med vindmøllestrøm.

Det betyder dermed at implementeringen af de nye teknologier skal ske samlet og med en overordnet global styring. Ingen kan jo have interesse $i$, at energi går tabt.

Herudover vil forskning i opsamling og opmagasinering af $\mathrm{CO}_{2}$ være fornuftig. Endnu er det på det eksperimenterende stadium, men hvis det kan bidrage til en løsning, skal det afprøves. Personligt er jeg skeptisk og afventer de forsøg, der er i gang.

Da drikkevandsproblemet risikerer at blive et meget stort problem i den nære fremtid visse steder i Verden, bør det undersøges, om havvand kan afsaltes på en billigere og mindre energikrævende metode, end tilfældet er i dag med de kendte teknologier.

\section{4) Kan vi gøre noget selv for at mindske den globale opvarmning?}

Ja, naturligvis kan vi alle gøre noget i det små i forhold til at bruge mindre energi. Men væsentligt er det at fortælle politikerne, at for eksempel de kollektive transportformer skal udvikles, og at vi vil have grøn energi i stedet for sort.

Den enkelte borgers energibesparelser luner i den enkeltes økonomi, men batter kun lidt i det store spil - ikke mindst set i lyset af den handel, der er med $\mathrm{CO}_{2}$-kvoterne.

\section{5) Hvad forventer du, at der kom- mer ud af klimakonferencen i Kø- benhavn senere $i$ år?}

Jeg forventer at politikerne vil vise, at de er opgaven voksen. Forhandlingerne er allerede i gang, og de fortsætter frem til topmødet. Jeg forventer - og håber - på en global aftale, hvor man enes om en reduktion af udledningen af drivhusgasserne i et omfang, så vi kan mindske temperaturstigningen. Aftalen skal være global og omfatte alle FN's lande, men sådan at udviklingslandene får deres del af goderne i form af udveksling af teknologi.

Forhåbentlig kan man derudover enes om, at den teknologiske udvikling skal samkøres globalt, så man ikke hovedkulds indfører teknologier i et land, som ikke kan samkøres med teknologier i et andet land. Kald det blot en global harmonisering af energistrukturen (så kan de være, at vi efterhånden ikke behøver at rejse med 7 forskellige stikpropper til Verdens forskellige stikkontakter.)

6) Hvordan tror du, at den "globale” temperatur ser ud om 100 år?

Jeg tror desværre, det bliver svært at holde stigningen på de berømte 2 grader. Mere realistisk er en 3 graders stigning i forhold til 1850.

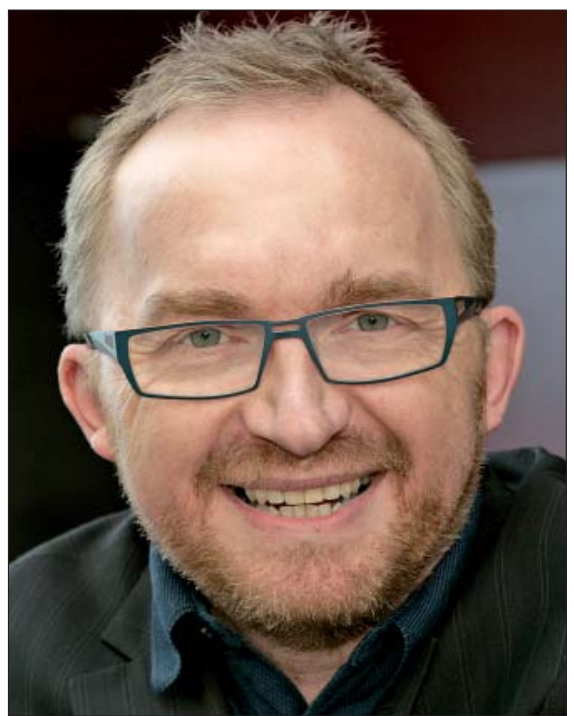

Jesper Theilgaard (f. 1955) er meteorolog og klimaekspert i DR 


\section{Martin Stendel}

anct

1) Hvad mener du, er den primære årsag til global opvarmning?

Det er forøgelsen af drivhusgaskoncentrationen i atmosfæren.

Med hensyn til de to vigtigste drivhusgasser, kuldioxid $\left(\mathrm{CO}_{2}\right)$ og metan $\left(\mathrm{CH}_{4}\right)$, er koncentrationerne på kun 150 år steget til niveauer, der er de højeste i mindst 650.000 år, men sandsynligvis ligefrem i 20 mio. år.

Denne øgning skyldes primært menneskelige aktiviteter. For $\mathrm{CO}_{2}$ er det afbrænding af fossile brændstoffer (kul, olie, gas) og en mindre andel fra afskovning, mens hovedkilderne for metan er landbrug og brug af fossile brændstoffer. Da strålingsegenskaberne af disse gasser er velkendte, kan man nemt udregne deres opvarmende effekt. Den observerede temperaturøgning er dog mindre end disse tal, fordi naturlige (fra vulkaner) og menneskeskabte aerosoler ( $f x$ fra afbrænding af biomasse) har en afkølende effekt.

\section{2) Er der nogle myter om global opvarmning, som, du mener, kan være misvisende i debatten?}

Der er flere ting som bidrager til denne misvisning.

Det skyldes bl.a. en dækning af emnet i medierne, som ikke passer til den generelle videnskabelige konsensus. Vurderet fra medierne får man indtrykket, at halvdelen af forskerne er tilhængere af alternative forklaringer på klodens opvarmning (som i øvrigt er uomstridt). Men i den videnskabelige litteratur er forholdet nærmere $3 \%$ skeptikere mod de $97 \%$, der ser menneskeskabte ændringer i drivhusgaskoncentrationer som hovedårsag.

Det bliver tit sagt, at det primært er Solen, som driver ændringerne i klodens temperatur. Rigtig nok får vi al energi fra Solen, men variationen i Solens indstråling (den såkaldte solarkonstant er ikke helt konstant, og der er ændringer i forbindelse med den 11-årige cyklus af Solens aktivitet) kan ikke forklare temperaturøgningen, vi har observeret de seneste år.

En anden myte er, at der ikke er taget hensyn til urbaniseringseffekten. Dette er ikke sandt, og vi kan med stor præcision korrigere for denne temperaturøgning.

Endnu en myte er, at vanddamp, den vigtigste drivhusgas, ikke er taget $\mathrm{i}$ betragtning i klimamodeller. Det er simpelthen forkert. Man kan nemt udregne, at vanddamps bidrag til den naturlige drivhuseffekt er omkring dobbelt så stort som bidraget fra kuldioxid. Men atmosfærens evne til at indeholde vanddamp stiger med stigende temperatur. Denne ekstra vanddamp bidrager til den menneskeskabte drivhuseffekt, og temperaturen vil stige yderlige (en såkaldt positiv tilbagekobling). Alt dette er en essentiel del af alle klimamodeller.

\section{3) Inden for hvilket forskningsom- råde synes du, at der bør afsættes (flere) penge - og hvad skal de bru- ges til?}

\section{Tre ting:}

1) Vi ved ikke nok om polare processer. Afsmeltning fra gletscherne fra Grønlands indlandsis er accelereret betydeligt mere, end alle modeller siger, og det samme gælder indskrumpningen af havisen i de sidste år. Grønlands iskappes massebalance er særdeles vigtig, fordi afsmeltningen bidrager til havniveauøgningen, i modsætning til afsmeltningen af havisen. Vi har brug for en meget mere detaljeret beskrivelse af massebalancen for indlandsisen.

2) Desuden skal vi sikre den bedst mulige satellitovervågning af alle de regioner, vi ikke har direkte observationer fra. Bortset fra polarområderne er det ørkener, den største del af oceanerne og næsten hele atmosfæren. I de sidste år er der blevet sparet en masse penge i de store internationale overvågningsprojekter baseret på satellitter. 3) Det tredje område er skæbnen for permafrost, både til lands og under havet. Hvis permafrostområderne på landet tør, og/eller metanhydratet på havbunden bliver ustabilt, kunne en stor mængde drivhusgasser blive frigivet til atmosfæren. Men vi ved ikke særligt meget om kulstofkredsløbet hverken på landet eller i havet for disse områder.

\section{4) Kan vi gøre noget selv for at mindske den globale opvarmning?}

Ja, faktisk en masse. Først og fremmest handler det om effektivisering af vores brug af energi. Det er ganske små ting som at slukke for standby på fjernsynet og andre redskaber, hvis man ikke har brug for det, at udskifte konventionelle pærer med elsparepærer osv. Det er også større ting som erstatning af benzinbiler med elbiler (hvis strømmen til dem ikke kommer fra fossilt brændsel). Men fordi udslippet af drivhusgasser skal reduceres med ca. 80 \% på lang sigt for at undgå farlige klimaændringer, kan vi ikke klare dette kun ved at gå over til vedvarende energi, medmindre der sker et teknologisk spring, og man vil derfor muligvis også have brug for lagring af $\mathrm{CO}_{2}$ under jorden.

\section{5) Hvad forventer du, at der kom- mer ud af klimakonferencen i Kø- benhavn senere $\mathrm{i}$ år?}

En efterfølger til Kyoto-aftalen. Der er stor enighed om, at det skal være slutresultatet af forhandlingerne, og den politiske situation er bedre end nogensinde, fordi alle er enige $i$, at USA skal være med i sådan en aftale.

\section{6) Hvordan tror du, at den "globa- le” temperatur ser ud om 100 år?}

3 grader varmere end i dag, hvis vi tager problemerne meget alvorligt og beslutter at agere med det samme, 5 grader hvis vi ikke gør det. Det er ikke umuligt at nå EU's mål om at holde temperaturøgningen under 2 grader i forhold til førindustriel tid (dvs., ca. 1,3 grader varmere end i dag), men det bliver nok meget vanskeligt, som det ser ud lige nu.

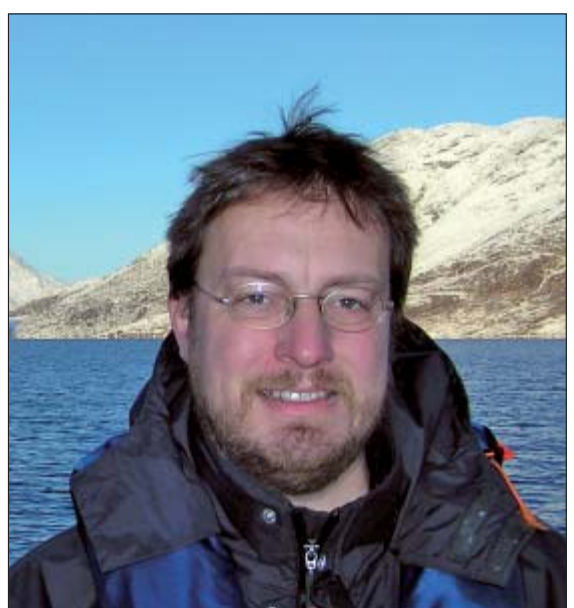

Martin Stendel (f. 1961) er seniorforsker ved Danmarks Meteorologiske Institut (DMI) 